\title{
Stability evaluation of modernized bank protections in a culvert construction
}

\author{
Mariusz Cholewa ${ }^{1 *}$, Karol Plesiński ${ }^{1}$, Katarzyna Kamińska $^{1}$ and Izabela Wójcik ${ }^{1}$ \\ ${ }^{1}$ University of Agriculture in Krakow, Faculty of Environmental Engineering and Lands Surveying, \\ Department of Hydraulic Engineering and Geotechnics, al. Mickiewicza 24/28, 30-059 Kraków, \\ Poland
}

\begin{abstract}
The paper presents stability evaluation of the banks of the Wilga River on a chosen stretch in Koźmice Wielkie, Małopolska Province. The examined stretch included the river bed upstream from the culvert on a district road. The culvert construction, built over four decades ago, was disassembled in 2014. The former construction, two pipes that were $1.4 \mathrm{~m}$ in diameter, was entirely removed. The investor decided to build a new construction in the form of insitu poured reinforced concrete with a $4 \times 2 \mathrm{~m}$ cross section. Change of geometry and different location in relation to the river current caused increase in the flow velocity and, as a consequence, erosion of both protected and natural banks. Groundwater conditions were determined based on the geotechnical tests that were carried out on soil samples taken from the banks and the river bed. Stability calculations of natural slopes of the Wilga River and the ones protected with riprap indicate mistakes in the design project concerning construction of the river banks. The purpose of the study was to determine the stability of the Wilga River banks on a selected section adjacent to the rebuilt culvert. Stability of a chosen cross section was analysed in the paper. Presented conclusions are based on the results of geotechnical tests and numerical calculations.
\end{abstract}

\section{Introduction}

Road culverts built in the last century often did not have any design projects. Lightweight traffic was assumed depending on the local economic, ground and technical conditions. It mainly concerned district and local roads where traffic was low at that time. Over the years traffic density increased, often the type of the road also changed. Modernization and rebuilding of the road infrastructure were necessary.

Nowadays it is required to fulfil the conditions set out in appropriate legal acts [1], detailed regulations of the Minister of Transport [2] and standards. Some of the constructions built several decades ago do not fulfil the current standards. The managers are trying as far as possible to make the necessary changes or rebuild aging constructions.

\footnotetext{
* Corresponding author: m.cholewa@ur.krakow.pl
} 


\section{Purpose}

The paper presents stability evaluation of the banks of the Wilga River on a chosen stretch in Koźmice Wielkie, Małopolska Province. The examined stretch included the river bed upstream from the culvert on a district road. The culvert construction, built over four decades ago, was disassembled in 2014. The former construction, two pipes that were $1.4 \mathrm{~m}$ in diameter, was entirely removed (Fig. 2b). The investor decided to build a new construction in the form of insitu poured reinforced concrete with a 4 × 2 m cross section (Fig. 3). Change of geometry and different location in relation to the river current caused increase in the flow velocity and, as a consequence, erosion of both protected and natural banks (Fig 4a,b). Groundwater conditions were determined based on the geotechnical tests that were carried out on soil samples taken from the banks and the river bed. Stability calculations of natural slopes of the Wilga River and the ones protected with riprap indicate mistakes in the design project concerning construction of the river banks. The purpose of the study was to determine the stability of the Wilga River banks on a selected section adjacent to the rebuilt culvert. Change of geometry and different location in relation to the river current caused increase in the flow velocity which lead to erosion of the banks. Stability of a chosen cross section was analysed in the paper. Presented conclusions are based on the results of geotechnical tests and numerical calculations.

\section{Characterization of the watercourse}

The source of the Wilga River is located in Pawlikowice (Wielicki Foothills). The river starts at the altitude of $370 \mathrm{~m}$ above sea level and after about $21 \mathrm{~km}$ it flows into the Vistula River at the altitude of $200 \mathrm{~m}$ above sea level. The beginning of the river meanders through stone formations and after that it flows only through finegrained cohesive soils (Fig. 1a). The outlet stretch was regulated and embankments were built so the urban area is protected against the backwater from the Vistula River. The Wilga River has an irregular flow. During floods it rises, the flow velocity increases and the river intensely erodes its bed creating often vertical slops that are $3 \mathrm{~m}$ high (Fig. 1b). When the water levels are low they do not exceed a few centimetres.
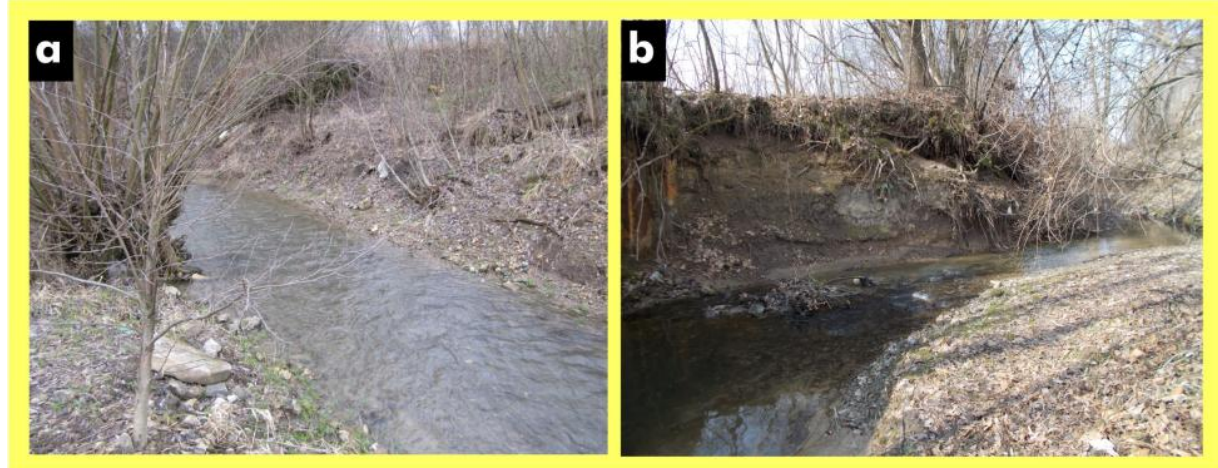

Fig. 1. Natural bed of the Wilga River a) upstream and b) downstream from the culvert. 


\section{Characterization of the road culvert}

\subsection{Condition of the construction before rebuilding}

The culvert was built in 1970s for lightweight horse and vehicle traffic. At that time the road was rather quiet and unpaved. In the following years the road was paved using metallurgical slag, later an asphalt surface was placed (Fig. 2a). Two reinforced concrete pipes with an internal diameter of $1.4 \mathrm{~m}$ were used as elements carrying water. The length of each pipeline was $10.3 \mathrm{~m}$ (Fig. 2b). The culvert was built without any design project since it was not necessary at the abovementioned economic conditions.
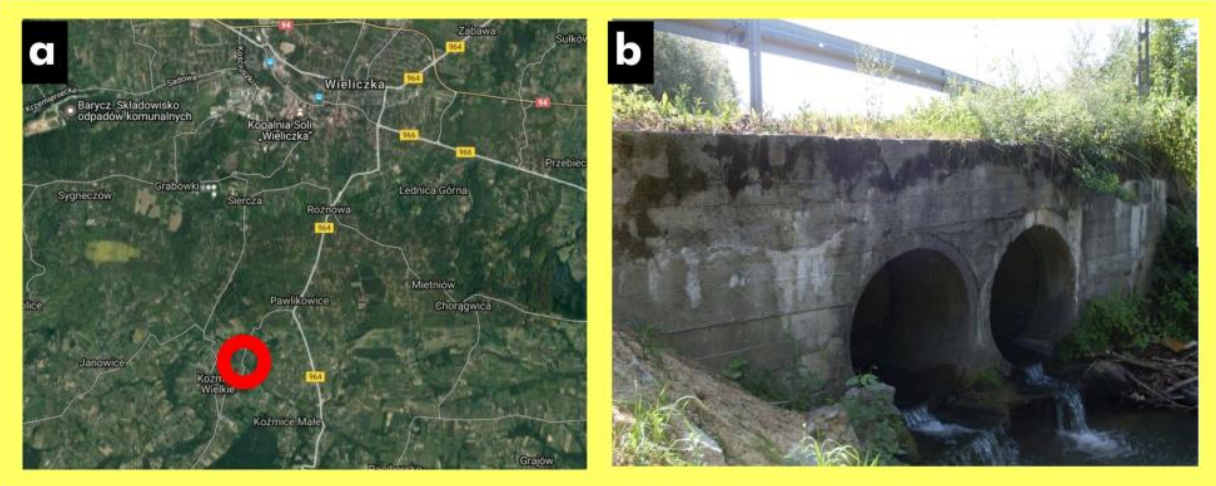

Fig. 2. a) Localization of the culvert b) condition of the construction before rebuilding

\subsection{Current condition of the construction}

Former culvert pipe was entirely disassembled. On the ground level where geotechnical parameters were appropriate the base of a new culvert was built. It is a reinforced concrete culvert poured on site; it is a closed frame based directly on solid clayey soils. The front walls are situated parallel to the road axis. The total length of the construction is $11.74 \mathrm{~m}$. The horizontal diameter is $4.00 \mathrm{~m}$, the vertical $2.00 \mathrm{~m}$ (Fig. 3) and the total carriageway is 10.34 m wide. 


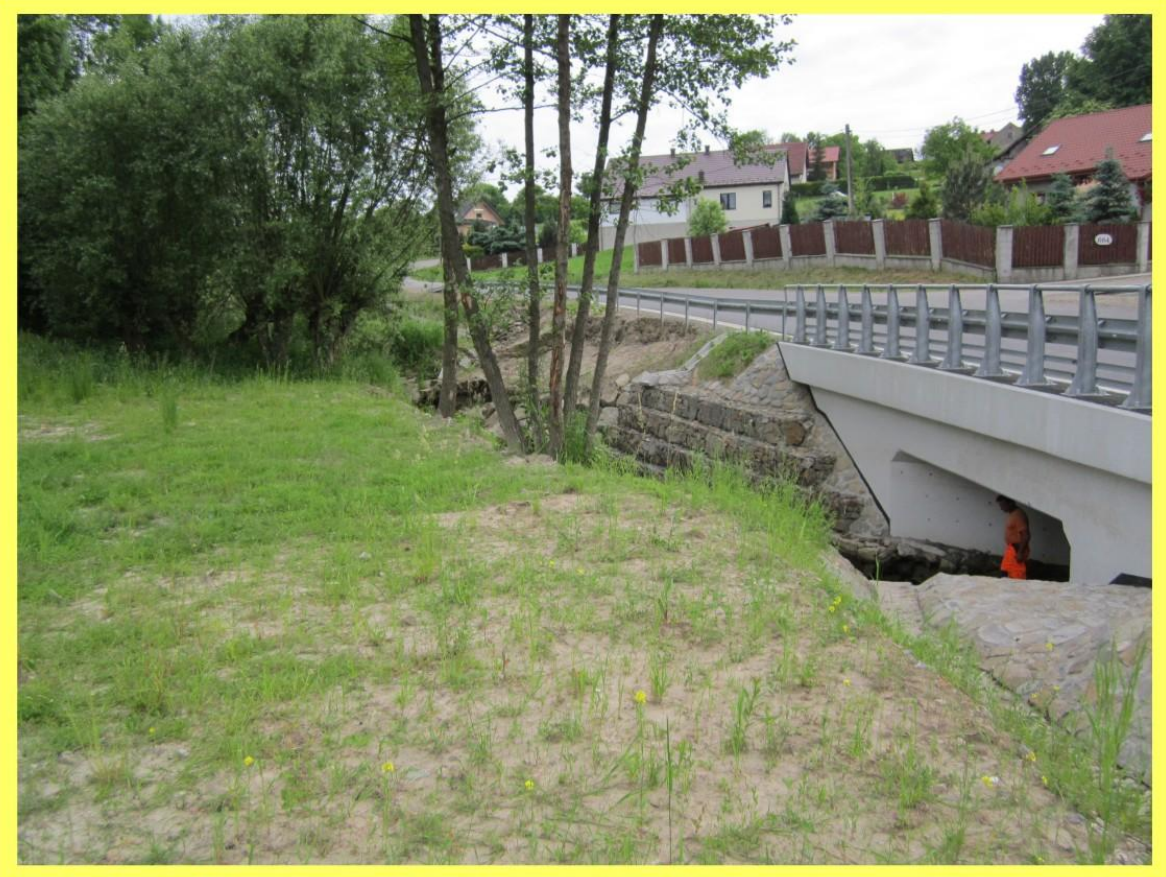

Fig. 3. Culvert on the upstream side and the view of damages

\subsection{Bank protection failure}

In the first year (2015) after the construction was finished the bank protection on the right side formed from riprap slid along with the soil from the slope fig. below.
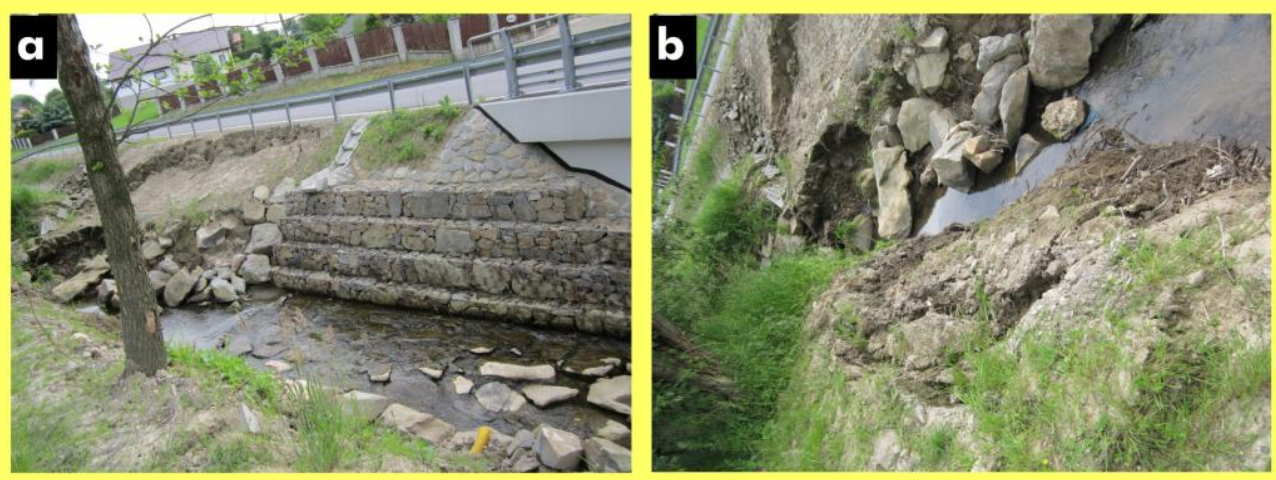

Fig. 4. The view of damages that occurred after the first year of exploitation a) from the downstream side and b) upstream side 
In the following year (2016) the improved protection was also gradually destroyed. Progressive failure of the bank is presented in fig. below.

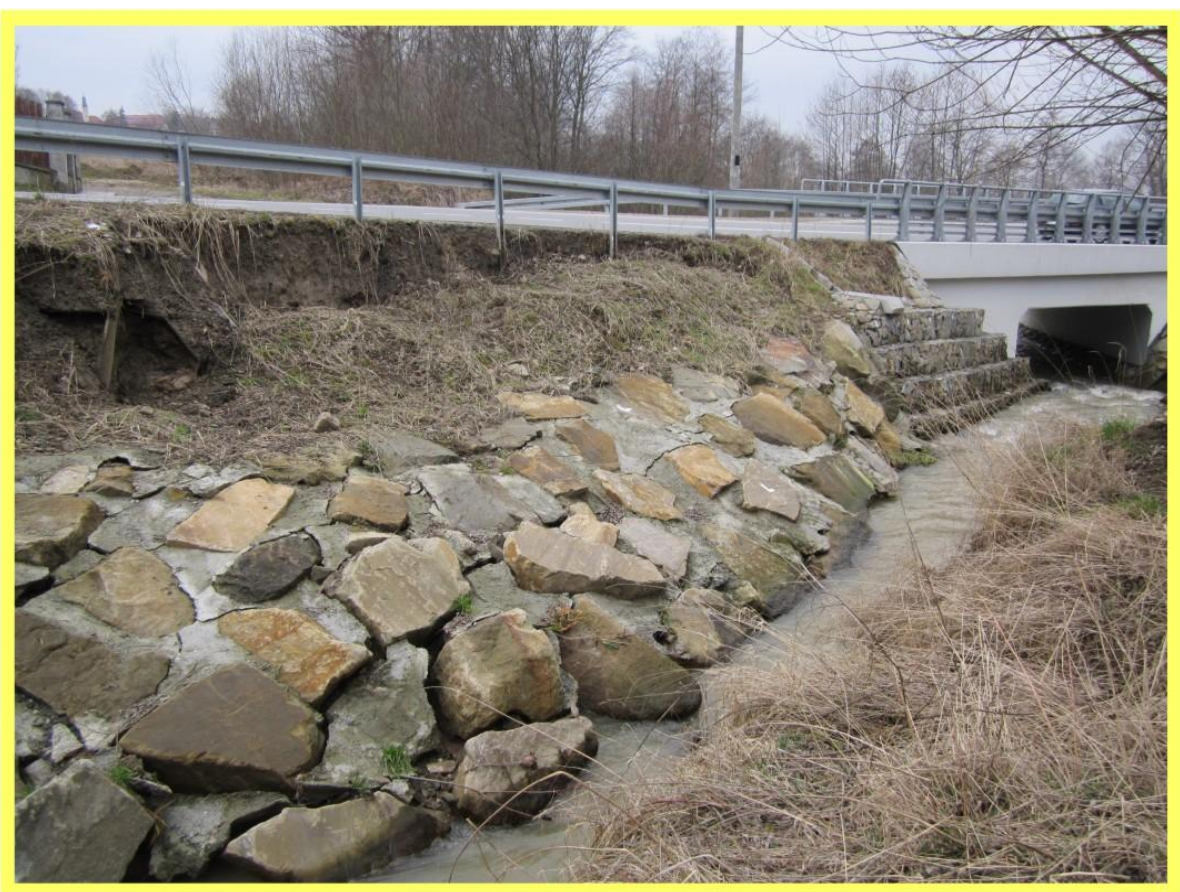

Fig. 5 The view of damages that occurred after the second year of exploitation from the upstream side

\section{Stability evaluation}

Slope stability evaluation can be performed using different methods [3, 4, 5, 6, 7]. Bishop's method, where the failure surface is circular-cylindrical, was used in the presented calculations. An attempt was made to determine whether the change of water conditions would influence the values of the factor of safety of a slope with a relatively dangerous inclination of 1.5:1. Two calculation models were assumed, starting with the one when the water level is low and then the one during the flood season in July. Surface load on the top of the road from traffic was also taken into account. 


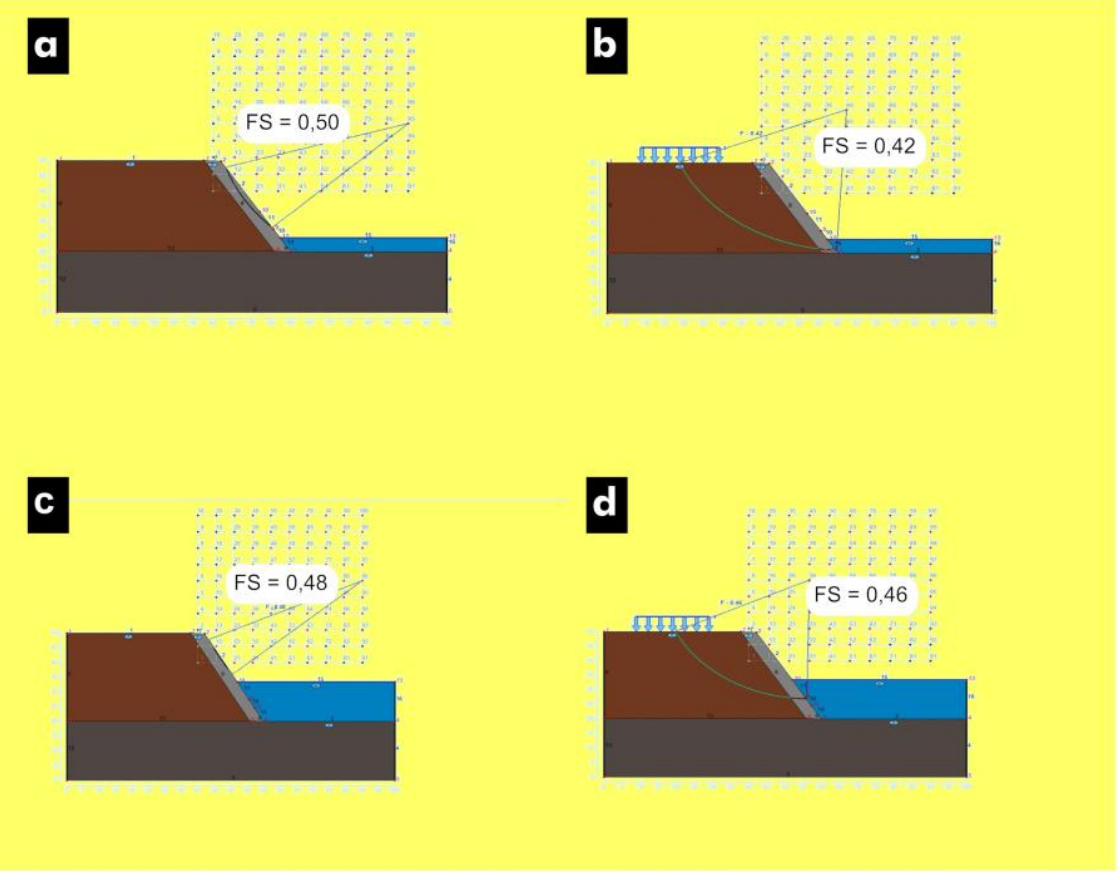

Fig. 6 Calculation scheme for the first model - at low water level a) without any load, b) vertical load of $1000 \mathrm{kN}$. Calculation scheme for the second model - at high water level c) without any load, d) vertical load of $1000 \mathrm{kN}$

Scheme presented in Fig. 6a shows the results of calculations at low water level parameters of the soil (Tab. 1) and geometry of the slope resulted in the value of the global stability factor of safety at 0.50 .

Table 1. Geotechnical parameters of the ground and slope soils

\begin{tabular}{|l|l|c|c|c|c|c|}
\hline No & Name & $\mathrm{I}_{\mathrm{L}}$ & $\rho\left[\mathrm{Mg} / \mathrm{m}^{3}\right]$ & $\mathrm{c}[\mathrm{kPa}]$ & $\varnothing\left[{ }^{0}\right]$ & Water \\
\hline 1 & soil of the slope - plastic clay & 0.50 & 2.00 & 26.00 & 16.00 & yes \\
\hline 2 & consolidated clayey ground & 0.00 & 2.10 & 40.00 & 10.00 & yes \\
\hline 3 & riprap & & & & & \\
\hline
\end{tabular}

Apart from total saturation of the slope, the scheme in Fig. $6 \mathrm{~b}$ assumes that there is a heavy transport vehicle on the top of the road, which was presented on the scheme as vertical load of $1000 \mathrm{kN}$. The factor of safety is 0.42 . Failure surface goes deeply into the road.

When the water level is high (Fig. $6 \mathrm{c}$,d) the values of the factor of safety do not differ significantly from the first model. Adequately it was 0.48 for the road without any load and 0.46 when there is a surface load of $1000 \mathrm{kN}$. 
Table 2. Results of the stability calculations

\begin{tabular}{|l|c|c|}
\hline \multirow{2}{*}{$\begin{array}{c}\text { Vertical load on the top of } \\
\text { the slope }\end{array}$} & $\begin{array}{c}1^{\text {st }} \text { model } \\
\text { low water level }\end{array}$ & $\begin{array}{c}2^{\text {nd }} \text { model } \\
\text { high water level }\end{array}$ \\
\cline { 2 - 3 } & \multicolumn{2}{|c|}{ Value of the factor of safety } \\
\hline No load & 0.50 & 0.48 \\
\hline $1000 \mathrm{kN}$ & 0.42 & 0.46 \\
\hline
\end{tabular}

All obtained results of the factor of safety are below the limit value of 1.0 (Tab. 2). When the water level is low it undermines the base of the slope and at the same time the water filtrates through the ground from the opposite side of the road embankment. During the low and medium flow, in the hole scour, the average values of velocity at measurement points were in range from $\mathrm{V}=0,210 \mathrm{~m} / \mathrm{s}$ to $\mathrm{V}=0,333 \mathrm{~m} / \mathrm{s}$. The maximum values at vertical measurements points were equal from $\mathrm{V}=0,223 \mathrm{~m} / \mathrm{s}$ to $\mathrm{V}=0,370 \mathrm{~m} / \mathrm{s}$. Then, the values measured above the river bed were in range from $\mathrm{V}=0,060 \mathrm{~m} / \mathrm{s}$ to $\mathrm{V}=0,32 \mathrm{~m} / \mathrm{s}$. The river bed is a natural drainage element for the adjacent area, so water supply to the river banks has to be taken into consideration $[8,9,10]$. When the water level is high the hydraulic pressure is compensated by the water pressure. Although another unfavourable phenomenon connected with water uplift pressure occurs (decrease in the value of density in the calculation scheme) $[11,12,13]$. It should also be noticed that high current velocity washes out and lifts the soil material.

\section{Summary}

The carried out tests and calculations gave consistent results concerning stability of the protected banks. With unfavourable geometry of the slope and groundwater conditions the calculated values of the factor of safety are below 1. Observations and tests were carried out during both low and high water levels. An important piece of information was the behaviour of the protected banks during drawdown - the hydraulic pressure contributed to the stability failure $[14,15]$.

Such results are influenced by the values of mechanical properties of the saturated soil in the protected banks $[16,17]$. The tests carried out in a shear box apparatus showed that the angle of internal friction is the same when the moisture content was close to the highplastic consistency. Uplift pressure of the filtrating water also has a negative influence in the tested crosssections. Although primarily it was the force connected with filtrating water that caused the bank protection to slide toward the flow cross-section.

The presented test object gives us the possibility to observe filtration phenomena - the critical ones - that result in reduction of the useful crosssection of the river. When the water level is high it infiltrates to the slope and it saturates the soil, reducing strength parameters in the saturated zone [18]. The main reason for the unfavourable values of the factor of safety is the infiltrating ground water as well as the velocity and uplift pressure of the flowing water. 


\section{References}

1. Ustawa z dnia 21 marca 1985 r. o drogach publicznych (Dz. U. Nr 14, poz. 60) z pózniejszymi zmianami.

2. Rozporzadzenie Ministra Transportu, Budownictwa i Gospodarki Morskiej z dnia 25.04.2012 w sprawie ustalenia geotechnicznych warunków posadowienia obiektów budowlanych (Dz. U. z 2012 r., poz. 463).

3. R. Handy, M. Spangler. Geotechnical Engineering. Soil and Foundation Principles and Practice. McGrawHill Professional New York, USA. (2006)

4. C. Venkataramaiah. Geotechnical Engineering. New Age International Publishers, Daryaganj, Delhi. (2006)

5. M. Borys, K. Mosiej. Wytyczne wykonywania ocen stanu technicznego i bezpieczeństwa wałów przeciwpowodziowych. Wydawnictwo IMUZ, Falenty. (2005)

6. R. Kulma, R. Zdechlik. Modelowanie procesów filtracji, Wydawnictwa AGH, Kraków. (2009)

7. L. Rembeza. Nieustalony przepływ filtracyjny przez wał przeciwpowodziowy $\mathrm{z}$ uszczelnieniami. Gosp.Wod. 9, 380-382. (2007)

8. T. Strzelecki, S. Kostecki, S. Żak. Modelowanie przepływów przez ośrodki porowate, Dolnośląskie Wydawnictwo Edukacyjne, Wrocław. (2008)

9. J. Chai, N. Miura, S. Shen. Performance of embankments with and without reinforcement on soft subsoil. Canadian Geotechnical Journal, 39(4), 838-848. (2002)

10. I. E. Alvarez, R. Rubio, H. Ricalde. Beach Restoration with Geotextile Tubes as Submerged Breakwaters in Yucatan, Mexico. Geotextiles and Geomembranes, 25(4-5), 233-241. (2007)

11. F. Gassner. Field Observation of GCL Shrinkage at a Site in Melbourne Australia. Geotextiles and Geomembranes, 27(5), 406-408. (2009)

12. C. C. Huang, Y. S. Tzeng, C. J. Liao. Laboratory Tests for Simulating Abrasion Damage of a Woven Geotextile. Geotextiles and Geomembranes, 25(4-5), 293-301. (2009)

13. A. Koffler, M. Choura, A. Bendriss, E. Zengerink. Geosynthetics in Protection Against Erosion for River and Coastal Banks and Marine and Hydraulic Construction. Journal of Coastal Conservation, 12(1), 11-17. (2008)

14. Ch. Huang, Ch. Liao. Abrasion damage of geogrids induced by turbid flow. Geotextiles and Geomembranes, 25(2), 128-138. (2007)

15. S. Lukman, J. A. Otun, D. B. Adie, A. Ismail, I. A. Oke. A Brief Assessment of a Dam and Its Failure Prevention. Journal of Failure Analysis and Prevention, 11(2), 97-109. (2011)

16. X. Junqiang, T. Li, X. Li, X. Zhang, Q. Zong. Daily Bank Erosion Rates in the Lower Yellow River Before and After Dam Construction. Journal of the American Water Resources Association (JAWRA), 50(5), 1325-1337. (2014)

17. W. T. Oh, S. K. Vanapalli. Influence of Rain Infiltration on the Stability of Compacted Soil Slopes. Computers and Geotechnics, 37(5), 649-657. (2010)

18. M. Cholewa, K. Plesiński, K. Kamińska, P. Baran. Warunki hydrodynamiczne przepływu rzeki Wilgi w okolicy przepustu drogowego w miejscowości Koźmice Wielkie. Acta Scientiarum Polonorum seria Formatio Circumiectus, 15(3), 45 - 56. (2016) 